\title{
Remittances and Economic Growth in Africa, Asia, and Latin American-Caribbean Countries: A Panel Unit Root and Panel Cointegration Analysis
}

\author{
Bichaka Fayissa* \\ Middle Tennessee State University \\ Murfreesboro, TN 37132 \\ Tel (615) 898-2385 \\ Fax (615) 898-5596 \\ Email: bfayissa@mtsu.edu \\ Christian Nsiah \\ Black Hills State University \\ Department of Accounting and Economics \\ Black Hills State University \\ Spearfish, SD 57799, U.S.A. \\ Tel (605) 642-6286 \\ Email: ChristianNsiah@bhsu.edu
}

\begin{abstract}
This study estimates the macroeconomic impact of remittances and some control variables such as openness of the economy, capital/labor ratio, and economic freedom on the economic growth of African, Asian, and Latin American-Caribbean countries using newly developed panel unit-root tests, cointegration tests, and Panel Fully Modified OLS (PFMOLS). We use annual panel data from 1985- 2007 for 64 countries consisting of 29 from Africa, 14 from Asia, and 21 from Latin America and the Caribbean region, respectively. We find that remittances, openness of the economy, and capital labor ratio have positive and significant effect on economic growth for all regions as a group and in each of the three in study. While the economic freedom index also has a positive and significant effect on growth in Africa and Latin America, however, its effect on the economic growth of Asia is mixed.
\end{abstract}

Key Words: Workers' Remittances, Economic Growth, Unit-Root tests, Error Correction Model, PFMOLS, Panel Data, Africa, Asia, Latin America/Caribbean

JEL Classification: E21 F21, G22, J61, O16

*Correspondences: Bichaka Fayissa, Department of Economics and Finance, Middle Tennessee State University, Murfreesboro, TN 37132, U. S.A. Tel (615)898-2385, Fax (615) 898-5596; Email: bfayissa@mtsu.edu 


\title{
Remittances and Economic Growth in Africa, Asia, and Latin American-Caribbean Countries: A Panel Unit Root and Panel Cointegration Analysis
}

\begin{abstract}
This study estimates the macroeconomic impact of remittances and some control variables such as openness of the economy, capital/labor ratio, and economic freedom on the economic growth of African, Asian, and Latin American-Caribbean countries using newly developed panel unit-root tests, cointegration tests, and Panel Fully Modified OLS (PFMOLS). We use annual panel data from 1985- 2007for 64 countries consisting of 29 from Africa, 14 from Asia, and 21 from Latin America and the Caribbean region, respectively. We find that remittances, openness of the economy, and capital labor ratio have positive and significant effect on economic growth for all regions as a group and in each of the three regions of the study. While the economic freedom index also has a positive and significant effect on growth in Africa and Latin America, however, its effect on the economic growth of Asia is mixed.
\end{abstract}

\section{Introduction}

In spite of the recent worldwide contraction in private financial flows to developing countries, remittances still continue to be a lifeline for more than 700 million people in developing countries. According to the World Bank estimates, remittances totaled $\$ 420$ billion in 2009 of which $\$ 317$ billion went to developing countries, involving some 192 million migrants or 3 percent of the world population (Massimo, 2010). For many developing countries, remittances represent a major part of international capital flows, surpassing foreign direct investment (FDI), export revenues, and foreign aid (Giuliano and Ruiz-Arranz, 2005). Figures 1, 2, 3, and 4 below depict the average annual growth rate of international financial flows in the form of remittances, overseas development assistance (ODA), and foreign direct investment (FDI) for African, Asian, and Latin American/Caribbean countries as a group and for each of the three regions, respectively for the years between 1985 and 2007 . FDI leads the way in all the regions in terms of growth followed by remittances, which have already surpassed official development assistance as a source of foreign financial inflows to the three regions

The main objective of this study is to estimate the long-run macroeconomic impact of remittances on the per capita GDP of African, Asian, and Latin American/Caribbean countries while controlling for some key sources of economic growth such as openness of the economy, capital/labor ratio, and economic freedom. As such, the study makes contributions to the existing literature on three fronts. First, the paper utilizes rich panel data covering three regions of the world (Africa, Asia, and Latin America/Caribbean) where the majority of the developing countries 
reside to investigate the relative impact of remittances on their economic growth as a group and/or individually. Secondly, we use newly developed panel unit-root tests, cointegration tests, and Panel Fully Modified OLS (PFMOLS to establish the long-run relationship between per capita GDP growth and remittances while taking into account some key control variables such as the openness of the economy, capital labor ratio, and the measure of economic freedom. Thirdly, the study provides a unified comparative analysis of the relative impact of remittances and other control variables of the economic growth African, Asian, and Latin/Caribbean countries. The findings suggest that remittances, openness of the economy, and capital labor ratio have positive and significant effect on economic growth for the regions as a group and in each of the regions.

The paper is organized as follows. The next section gives a brief review of the literature. Section 3 describes the data and empirical methodology. The empirical results are presented in section 4. The final section draws conclusions based on the results.

\section{A Review of Selected Literature}

In the case of Africa, a recent joint study by the World Bank and the Central Bank of Kenya suggests that money sent to Africa by those living abroad is estimated at $\$ 21$ billion and is expected to grow by two percent in 2010. While such remittance flows represent a significant share of the gross domestic product (GDP) for many African countries, however, it is not as high as for the other regions of the world such as Latin American, or Asian countries (Otieno, 2010). For instance, remittances to the Philippines in Asia and Mexico in Latin America alone were roughly the same as those received by the whole of sub-Saharan Africa in 2010. The top ten recipients of remittances in Africa in 2010 include Nigeria (US\$10 billion), Sudan (US\$3.2 billion), Kenya (US\$1.8 billion), Senegal (US\$1.2 billion), South Africa (US\$1.0 billion), Uganda (US\$0.8 billion), Lesotho (US\$0.5 billion), Ethiopia (US\$387 million), Mali (US\$385 million), and Togo (US\$302 million).

Based on household survey data from various African countries, few empirical studies have investigated the role of remittances in reducing poverty (Lucas and Stark, 1985; Adams, 1991; Sander, 2004; Azam and Gubert, 2005; Adam and Page, 2005; Adam, 2006). Perhaps, the aggregate impact of remittances have been disregarded for at least two reasons. One theoretical strand suggests that workers' remittances are mainly used for consumption purposes and, hence, have minimal impact on investment and may, in fact, reduce the incentive of the recipients to 
work. In other words, remittances are widely viewed as compensatory transfers between family members who lost skilled workers due to migration.

Other studies by Stark and Lucas (1988), Taylor (1992), Faini (2002), and Adams and Page (2005) find a positive relationship between remittances and economic growth based on 113 countries. Focusing on the experience of 101 developing countries, however, recent studies by Chami et al. (2005) and IMF (2005) find negative and no impact of remittances on economic growth.

Stahl and Arnold (1986), however, argue that the use of remittances for consumption may have a positive effect on growth because of their possible multiplier effect by stimulating business development in the recipient countries. Moreover, remittances respond to investment opportunities in the home country as much as to charitable or insurance motives. Many migrants invest their savings in small businesses, real estate or other assets in their own country because they know local markets better than in their host countries, or probably expecting to return in the future. In about two-thirds of developing countries, remittances are mostly profit-driven and increase when economic conditions improve back home. Such external monetary flows are particularly used for investment where the financial sector does not meet the credit needs of local entrepreneurs (Institute of Development Studies, id21 insights, \#60, January, 2006).

Using panel data set of developing Asia and the Pacific countries during the period 1993-2003, Jongwanich (2007) finds that remittances constitute the largest foreign exchange earnings and represent more 10 percent of GDP. A recent study by Vargas-Silva, et al. (2009), using panel data for more than 20 countries in the Asian region for 1988-2007, also finds that remittances positively affect home country real gross domestic product (GDP) per capita growth, i.e. a $10 \%$ increase in remittances as a share of GDP leads to a $0.9-1.2 \%$ increase in GDP growth.

According to a World Bank study (2008), Latin America and the Caribbean countries received around US\$50 billion in remittances in 2005. This represents about 70percent of foreign direct investment (FDI) and is almost 8 times more than official development assistance (ODA) to the region. In terms of sheer volume, Mexico outpaces the pack in the region with over US\$25 billion, followed by Brazil (US\$7.2 billion), Colombia (US\$4.8 billion), Guatemala (US\$4.3 billion), El Salvador (US\$3.8 billion), the Dominican Republic (US\$3.1 billion), Peru (US\$2.9 billion), Ecuador (US\$2.8 billion), and Honduras (US\$2.7 billion), according to the IDB (Grogg, 2009). However, on a per capita basis, El Salvador gets the most, followed by the Dominican Republic, Honduras, Guatemala, and Mexico rounding up the top five recipients in that order. Using a large cross-country panel dataset, 
Acosta et al. (2008) find that remittances in Latin American and Caribbean countries (LAC) have increased economic growth and reduced inequality and poverty. While Giuliano and Arranz (2009) find that remittances pave the way for financial development leading to economic growth, Amuedo-Durantes and Pozo (2004) and Chami, et al. (2005) argue that remittances may have a deleterious effect on economic growth otherwise known as the "Dutch disease" by reducing the incentives for labor force participation of the recipients. Thus, we cannot, a priori, predict the direction, or the size of the impact of remittances on the economic growth based on the above discussions. The next section highlights the methodology and data of the study.

\section{Empirical Methodology and Data}

\subsection{Panel unit root tests}

To investigate the causal relationship and co-movements between remittances and per capita income, we first check for the stationarity of our data. Recently, there has been a hightened development of panel-based unit root tests ( Hadri, 1999; Breitung, 2000; Choi, 2001; Levin, Lin and Chu, 2002; Im, 2003; Breitung and Das, 2005). These studies have shown that the panel unit root tests are less likely to be subject to Type II error and as such are more powerful than tests based on times series data.

Due to the unbalanced nature of our dataset and also some gaps in the individual time series, we employ the Fisher-type Augment Dickey Fuller (ADF) tests as presented by Choi $2001^{1}$ which do not require a balanced dataset and allow for gaps in the individual series. ${ }^{2}$ The ADF specification can be written as:

$$
\Delta y_{i t}=\rho_{i} y_{i, t-1}+z_{i t}^{\prime} \gamma_{i}+v_{i t}
$$

where $\mathrm{i}=1 \ldots \ldots \mathrm{N}, \mathrm{t}=1 \ldots \ldots \mathrm{T}$, and $v_{i t}$ denotes the stationary error term of the $i$ th member in period $t$, respectively. $\mathrm{y}_{\text {it }}$ refers to the variable being tested, $z_{\text {it }}$ represents control variables in the model (including remittances) with panelspecific means, time trends, or nothing depending on the options specified. If $\mathrm{z}_{\mathrm{it}}=1$, then $z^{\prime}{ }_{i t} \gamma_{i}$ will denote fixedeffects. On the other hand, we can specify a trend scenario where $z_{i t}^{\prime}=(1, \mathrm{t})$ such that $z_{i t}^{\prime} \gamma_{i}$ represents fixed-effects and linear time trends. We can also specify $z^{\prime}{ }_{i t}$ non-constant and omit the $z^{\prime}{ }_{i t} \gamma_{i}$ term altogether.

In testing for panel-data unit roots, Fisher-type tests conduct the unit-root tests for each panel individually and then combine the $p$-values from these tests to produce an overall test (an approach used mostly in meta-

\footnotetext{
${ }^{1}$ See also Maddala and Wu (1999)

${ }^{2}$ See STATA 11 handbook.
} 
analysis). Note that in this context, we perform a unit-root test on each of our panel units $i$ separately and then we use their combined p-values to construct a Fisher-type test to investigate whether or not the series exhibit a unit-root. The null hypothesis in this case is $\mathrm{H}_{\mathrm{O}}: \rho_{i}=1$ for all $i$ versus the alternative hypothesis of $\mathrm{H}_{\mathrm{a}}: \rho_{i}<0$ for some $i$. This routine provides 4 different unit-root test methods as proposed by Choi (2001). The first three tests differ in whether they use the inverse chi-square $(\mathrm{P})$, inverse normal $(\mathrm{Z})$, or inverse logit $(\mathrm{L})$ transformation of the $p$-values while the fourth test is a modification of the inverse chi-square method which is suitable when the sample $(N)$ is large. Choi (2001) shows that the Z-statistic offers the best trade-off between size and power, and as such suggests its use in applications. In the next sub-section, we address the issue of panel cointegration tests to determine whether GDP per capita and the control variables move together in the long-run.

\subsection{Panel Cointegration Tests}

As a second step for checking the long-run relationship between per capita income growth and remittances, we employ the Error-correction model for cointegration tests of panel data as described by Westerlund (2007). Unlike models which are based on residual dynamics (such as Pedroni, 2004), these tests propose four new panel tests of the null hypothesis of no cointegration which are based on the structural rather than dynamics and, therefore, do not impose common factor restrictions. Two methods are designed to test the alternative hypothesis that the panel is cointegrated as a whole, while the other two test the alternative hypothesis that there is at least one individual member of the panel that is cointegrated. In a nutshell, if the null hypothesis of no error correction is rejected, then the null hypothesis of no cointegration is also rejected. We note here that the error-correction tests assume the following data-generating process:

$$
\Delta y_{i t}=\delta^{\prime}{ }_{i} d_{t}+\alpha_{i}\left(y_{i, t-1}-\beta_{i}^{\prime} x_{i, t-1}\right)+\sum_{j=1}^{p_{t}} \alpha_{i, t-j}+\sum_{j=-q t}^{p_{t-1}} \gamma_{i j} \Delta x_{i, t-j}+\varepsilon_{i t}
$$

where $\mathrm{t}=1, \ldots, \mathrm{T}$ and $\mathrm{i}=1, \ldots, \mathrm{N}$ denote the time-series and cross-sectional units, respectively; $\mathrm{d}_{\mathrm{t}}$ contains the deterministic components for which there are three possible cases that can occur including: $(1) d_{t}=0$, thus, equation (1) has no deterministic terms, (2) $\mathrm{d}_{\mathrm{t}}=1$, thus, $\Delta y_{i t}$ is generated with a constant, and $(3) \mathrm{d}_{\mathrm{t}}=(1, \mathrm{t})$, thus, $\Delta y_{i t}$ is generated with both a constant and a trend. In our case, $y_{i t}$ denotes the log of real per GDP capita of country $i$ at time $t$, and $x_{i t}$ denotes the log of remittances to country $i$ at time $t$. 
Equation (2) can be rewritten as:

$$
\Delta y_{i t}=\delta_{i}^{\prime} d_{t}+\alpha_{i}\left(y_{i, t-1}-\lambda_{i}^{\prime} x_{i, t-1}\right)+\sum_{j=1}^{p_{t}} \alpha_{i j} \Delta y_{i . t-j}+\sum_{j=-q t}^{p_{t-1}} \gamma_{i j} \Delta x_{i, t-j}+\varepsilon_{i t}
$$

where $\lambda_{i}^{\prime} \mathrm{i}=-\alpha_{\mathrm{i}} \beta_{i}^{\prime}$. The parameter $\alpha_{\mathrm{i}}$ determines the speed at which the system $y_{i, t-1}-\beta_{i}^{\prime} x_{i, t-1}$ corrects back to the equilibrium relationship after a sudden shock. If $\alpha_{i}<0$, then the model is error-correcting, implying that $y_{i t}$ and $\mathrm{x}_{\mathrm{it}}$ are cointegrated. If $\alpha_{\mathrm{i}}=0$, then there is no error correction and, thus, no cointegration. We can, thus, state the null hypothesis of no cointegration as $\mathrm{H}_{\mathrm{O}}: \alpha_{\mathrm{i}}=0$ for all $i$. The alternative hypothesis depends on what is being assumed about the homogeneity of $\alpha_{i}$. Westerlund (2007) proposes four statistical tests including two group-mean tests and two panel-mean tests. The group-mean tests do not require the $\alpha_{i}$ 's to be equal and as such allow one to test the null hypothesis against the alternative hypothesis of $\mathrm{H}_{\mathrm{g}}$ : $\alpha_{\mathrm{i}}<0$ for at least one $\mathrm{i}$. In the case of the panelmean statistic, we test the null against the alternative hypothesis of $\mathrm{H}_{\mathrm{p}}: \alpha_{\mathrm{i}}=\alpha<0$ for all $i$. The postulated relationship between our variables of interest allows for a linear time trend:

$$
\ln \left(Y_{i t}\right)=u_{i}+\tau_{i} t+\beta_{i} \ln \left(X_{i t}\right)+\varepsilon_{i t}
$$

We perform the cointegration tests using $A I C$ to choose an optimal lag and lead lengths for each series and with the Bartlett kernel window width set according to $4 *(T / 100)^{2 / 9} \sim 3 .^{3}$ Since part of our interest lies in investigating regional differences, we present the cointegration test results for the overall and also for the 3 regions (Africa, Asia, and Latin America) under consideration. Having verified the log-run relationship between the GDP per capita and the control variables, we now turn to the estimation of the log-run impact of the control variables on GDP per capita using Panel Fully Modified Ordinary Least Squares Method (PFMOLS) in the next sub-section.

\subsection{Panel Fully Modified Ordinary Least Squares Test (PFMOLS)}

We employ an autoregressive distributive lag (ARDL) dynamic panel specification in the following form:

$$
y_{i t}=\sum_{j=1}^{p} \gamma_{i j} y_{i, t-j}+\sum_{j=0}^{q} \delta_{i j}^{\prime} x_{i, t-j}+\mu_{i}+\varepsilon_{i t}
$$

where $\mathrm{y}_{\mathrm{it}}$, denotes the real per capita income of the $i$ th country in period $t$, respectively $(\mathrm{i}=1 \ldots \ldots, \mathrm{N}, \mathrm{t}=1 \ldots \ldots \mathrm{T}), . \mathrm{X}_{\mathrm{it}}$ is a $\mathrm{K}^{*} 1$ vector of explanatory variables; $\gamma_{i j}$ 's are scalars and $\delta_{i t}$ 's are a $\mathrm{K}^{*} 1$ vector of coefficients. If the variables in

\footnotetext{
${ }^{3}$ We followed Newey and West (1994)
} 
equation (5) are $\mathrm{I}(1)$ and cointegrated, then the error term is an $\mathrm{I}(0)$ process for all of our groups $i$. An important feature of variables that are cointegrated is their responsiveness to deviations from the long-run state, suggesting an error-correcting model where the short-run dynamics (shocks) of our variables will adjust to the long-run equilibrium are influenced by deviations from long-run equilibrium. This allows us to re-parameterize equation (5) into an error-correcting model written as:

$$
\Delta y_{i t}=\emptyset_{i}\left(y_{i, t-1} \theta_{i}^{\prime} X_{i t}\right)+\sum_{j=1}^{p-1} \gamma_{i t} \Delta y_{i, t-1}+\sum_{j=0}^{q-1} \delta_{i j}^{\prime} \Delta X_{i, t-j}+\mu_{i}+\varepsilon_{i t}
$$

where $\emptyset_{i}$ denotes the error-correcting speed of adjustment term. If $\emptyset_{i}=0$, then there is no evidence for a long-run relationship between the dependent variable and our regressors. The parameter $\emptyset_{i}$ is expected to be significantly negative under the previous assumption that the variables return to a long-run equilibrium. The vector $\theta_{i}^{\prime}$ is of particular importance because it contains the long-run relationships (elasticities) between the per capita income and the control variables. ${ }^{4}$

We employ the pooled-mean estimator for the dynamic panel data advocated by Pesaran, et al. (1998 \& 1999) in estimating the long-run worker remittance elasticity of growth. They propose a maximum likelihood type "pooled-mean group" (PMG) estimator which combines pooling and averaging individual regression coefficients in equation (6). In this case, one could use a conditional error correction framework where long-run elasticities are constrained to be the same, but short-run dynamics are allowed to vary over the cross-sections.

The PMG estimators have two key advantages over other commonly used estimators in the literature. Compared to the static fixed-effects estimator, the PMG estimator allows for dynamics while the static fixed-effects model do not. In comparison to the dynamic fixed-effects estimator, the PMG estimator allows the short-run dynamics (shocks) and error variances to differ across cross-sections. Another pertinent advantage is that the underlying auto-regressive distributed lag (ARDL) structure dispenses with the importance of the unit root pretesting of the variables in question. As long as there is a unique vector which defines the long-run relationship

${ }^{4} \emptyset=-\left(1-\sum_{j=1}^{p} \gamma_{i t}\right), \theta_{i}=\frac{\sum_{j=0}^{q} \delta_{i j}}{\left(1-\sum_{k} \gamma_{i k}\right)}, \gamma_{i j}^{*}=-\sum_{m=j+1}^{p} \gamma_{i m} \quad j=1 \ldots \ldots P-1$, and $\delta_{i j}^{*}=-\sum_{m=j+1}^{q} \delta_{i m} j=1 \ldots \ldots . . q-1$. 
among our variables of interest, it is of no consequence if the variables are either $\mathrm{I}(1)$, or $\mathrm{I}(0)$ since the PMG estimates of an ARDL specification will yield consistent estimates. ${ }^{5}$

\subsection{Data}

We employ annual panel dataset for 64 countries for the period between 1985 and 2007. The data are based on 29 African, 14 Asian, and 21 Latin American/Caribbean countries. The use of annual data is important for our analysis because they help us to circumvent problems associated with seasonality (Vanegas \& Croes, 2003). They also help us not to make an unwarranted assumption of homogeneity among the countries in the sample. Per capita income, remittances, capital/labor ratio, and openness to trade data come from the World Bank's 2010 World Development Indicators Dataset. The Freedom variable is constructed from political rights, and civil liberty data are procured from Freedom House of the Heritage Foundation. The data description and summary statistics are provided in Tables $1 \mathrm{a}$ and $1 \mathrm{~b}$ below.

\section{Tests and Empirical Results}

\subsection{Unit-root Test}

For the stationarity test of our data, we first apply the Fisher-Type ADF unit root tests which are presented in levels and difference in tables 2 and 3, resulting in 4 different test statistic: Inverse Chi Square (P), Inverse Normal (Z), Inverse Logit ( $\left.\mathrm{L}^{*}\right)$, and Modified Inverse Chi Square (Pm). Choi (2001) suggests that the inverse normal $\mathrm{Z}$ statistic should be used for stationarity tests because it offers the best trade-off between size and power. Low $\mathrm{Z}$ and $\mathrm{L}$ values cast doubt on the null hypothesis of unit-roots whereas large $\mathrm{P}$ and Pm values cast doubt on the null hypothesis. Note here that our test statistics are calculated with a one-period lag, individual effects, and time trends.

The results reported in Table 2 show that the per capita GDP, capital/labor ratio, openness, and the freedom or personal rights are not entirely stationary in levels. This is especially true for the freedom (personal rights) variable which is not significant for almost all the regions, except for the Latin America and Caribbean region using the $\mathrm{P}$ and Pm test statistics. Table 3 presents the same test results estimated in first difference. As can be readily observed from Table 3, all the tests show that the variables are stationary in first difference at the 1 percent level of

\footnotetext{
${ }^{5}$ Reverse causality is not a problem if the variables are I(1). This is because in that case there exist the superconsistent property.
} 
significance. It is, thus, reasonable to assume that these variables are co-integrated of order zero i.e. I(0) in first difference.

\subsection{Cointegration Tests}

Table 4 presents the cointergration test results for our sample of countries organized by the geographical regions. The group-mean and panel statistics for the overall sample including, African, Latin American and Caribbean countries are all significant. These results indicate that we have a case of error correcting model, at least in the case of African and Latin American and Caribbean countries, meaning that we can reject the null hypothesis of no cointegration for the African and Latin American/Caribbean countries. This result suggests that there is a longrun relationship between remittances and the economic growth for African, Latin American, and Caribbean countries. In the case of Asian countries, however, the error-correction models exhibit mixed results. Whereas the group $(\mathrm{Ga})$ and the panel fixed-effects $(\mathrm{Pa})$ statistics reject the null at the 1 percent level, the panel time trend $(\mathrm{Pt})$ and the group panel (Gt) statistics fail to reject the null hypothesis. Since two out of the four statistics reject the null-hypothesis of no error-correction, we choose to interpret the results as a partial evidence of cointegration between remittances and economic growth for Asian countries. ${ }^{6}$

\subsection{Panel Fully Modified OLS (PFMOLS) Estimation}

Having established that the variables are stationary and exhibit long-run cointegration in the previous subsections, we now estimate the long-run impact of workers' remittances and the control variables on economic growth of African, Asian, and Latin-Caribbean countries using the Panel Fully Modified Ordinary Least Squares (PFMOLS) estimator. The choice of the PFMOLS over Ordinary Least Squares (OLS) estimator is based on the fact that it has the dual advantage of correcting for both serial correlation and potential endogeneity problems that may arise when the OLS estimator are used. We estimate four models, one for our whole sample and one for each of the three regions under consideration. Table 5 presents the results of our PFMOLS estimations.

The negative and significant values of the parameter $\emptyset$ for all our models indicate that there is a long-run relationship between our variables. Our estimated long-run impact of openness to trade and new fixed capital to labor ratio have the expected signs. Specifically, our results indicate that the openness and new fixed capital labor

\footnotetext{
${ }^{6}$ Note that Westerlund (2007) argues that we should rely more on the Pt test in our analysis because it is more robust. The reasoning is that since the Pa statistic is normalized by $\mathrm{T}$, this may cause the test statistic to reject the null too frequently. His simulations also show that the Pt statistics is more robust to cross-sectional correlations.
} 
ratio all have significantly positive long-run impact on economic growth for the whole sample and for each of the regions under consideration.

While personal freedom is shown to have a positive long-run impact on growth in Africa and Latin America and the Caribbean, there is a negative but insignificant effect of personal freedom on Asian economic growth. This result can be explained by the phenomenal economic growth of countries such as China which have had very checkered personal freedom histories. The lagged growth is significantly negative indicating somewhat of a catch-up effect. This is to say that countries which experience significantly large growth are less likely to experience such rapid growth trend in the future. One can also link this observation with expectations where country which is not doing well today, we can expect for it to do better in the future while high growth rate countries are expected to slow down somewhat in the near future.

The results presented above indicate that the flow of remittance have a positive and significant long-run effect on economic growth in our overall sample and also in the different geographical regions under consideration. These geographical differences may be caused by the differences in the dynamics of how remittances are transmitted and/or used in the different regions. For example, Latin American and Caribbean countries may enjoy a better financial mechanism that facilitates the efficient transmission of remittances in comparison to countries in Africa and Asia. Furthermore, expectations and culture of the senders and recipients of remittances while similar in one region may differ from one region to the other. For example, remittances may be largely used for investment purposes in one region, whereas it may be used mainly for current consumption supplementation in the other, thus having a significantly positive long-run impact in the region where it is largely used for investments, and either a negative, insignificant, or slightly positive impact on the long-run economic growth in areas where it is used largely to supplement consumption.

Comparatively, our results indicate that a $10 \%$ increase in remittances lead to a $0.13 \%, 1.56 \%$, and $0.3 \%$ long-run economic growth in Africa, Asia, and Latin America and Caribbean regions, respectively. These results indicate that remittances contribute more to the long-run per capita growth in Asia than in the other regions under consideration, suggesting that there are differences in the transmission costs and uses of remittances for economic growth in the recipient regions.

\section{Conclusions and Policy Implications}


This study investigates whether there is a long-run stable relationship between GDP per capita and remittances and other salient control variables such as the openness of the economy, capital/labor ratio, and economic freedom for 29 African, 14 Asian, and 19 Latin/Caribbean countries. We use annual panel data spanning over the 1985-2007 period and recently developed panel unit (Choi, 2001) and error correction model by Westerlund (2007) and Pedroni (2004) to test the stationarity and cointegration of the panel data series. Overall, our findings are consistent with other studies that have investigated the impact of worker remittances to economic growth. However, our findings are much more reliable because we use a superior dataset covering a larger group of countries and a longer time series, and employ superior and newer estimation methodologies.

The results show that remittances do, indeed, have a statistically significant long-run impact on economic growth in all three regions as a group and much more pronounced for the Asian region than the African or Latin/Caribbean regions, partly owing to the regional differences in the transaction costs and the use of remittances. In an era when there is strong opposition to the disbursement of the traditional sources of development financing in the form of foreign aid, foreign direct investment (FDI), and private transfers, remittances serve as a life line for development projects. To insure that remittances efficiently and sufficiently flow to where there are acute needs, governments may consider to foster increased competition and technological innovation with a view of increasing formal flows and financial deepening. 


\section{References}

Acosta P, Calderón C, Fajnzylber P, López H (2006) Remittances and development in Latin America, World Economy 29: 957-987.

Acosta P, Calderón C, Fajnzylber P, and López H (2008) What is the impact of International migrant remittances on poverty and inequality in Latin America? World Development 36: 89-114.

Adams RH (1991) The Effects of international remittances on poverty, inequality, and development in Egypt. IFPRI Research Report 86 (Washington, IFPRI).

Adams RH (2006) Remittances and poverty in Ghana. World Bank Policy Research Paper 3838 (Washington: World Bank).

Adams R, Page J (2005) Don international migration and remittances reduce poverty in developing countries? World Development 33:1645-1669.

Amuedo-Dorantes C, Pozo S (2004) Workers' remittances and the real exchange rate: a paradox of gifts, World Development, 32: 1407-1417

Azam, J P, Gubert F (2006) Migrants' remittances and household in Africa: a review of evidence, Journal of African Economies, 15: 426-462.

Beck T, Levine R, Loayza N (2000) Finance and Sources of Economic Growth. Journal Financial Economics 58: 263-300.

Breitung J (2000) The local power of some unit root tests for panel data. In B.Baltagi (ed.), Nonstationary Panels, Panel Cointegration, and Dynamic Panels, Advances in Econometrics, 15. JAI: Amsterdam, 161-178

Breitung J, Das S (2005) Panel unit root tests under cross-sectional dependence. Statistica Neerlandica 59: 414-433.

Brown R P C (1994) Migrants' remittances, savings, and financial development and growth, IMF Working paper 05/234.

Chami R, Fullenkamp C, Jahjah J (2005) Are immigrant remittance flows a source of capital for development? IMF Working Paper 01/189, IMF, Washington, DC.

Choi In (2001) Unit root tests for panel data. Journal of International Money and Finance 20:249 - 272.

Cirasino M (2010) Trends in the average cost of migrant remittance Services, Access Finance (A Bi-Monthly Newsletter which disseminates information on improving access to financial services), June 2010, Issue No. 32.

Garcia-Fuentes PA, Kennedy PL (2009) Remittances and economic growth in Latin America and the Caribbean: the impact of the human capital development. Southern Agricultural Economics Association, 2009 Annual Meeting, January 31-February 3, 2009, Atlanta, Georgia

Giuliano P, Ruiz-Arranz M (2005). Remittances, financial development, and growth, IMF 05/ 234, IMF Washington DC. 
Giuliano P, Ruiz-Arranz M (2009) Remittances, financial development, and growth. Journal of Development Economics 90: 144-152

Grogg P (2009) Latin America: remittances drop will hurt poor. http://ipsnews.net/news.asp?idnews=47032.

Gupta S, Pattillo C, Wagh S (2007) Making Remittances Work for Africa Finance \& Development, 44: 1 -9.

Hadri K (1999) Testing for stationarity in heterogeneous panel data. Econometrics Journal, 3: 148-161.

Im KS, Pesaran MH, Shin Y (2003)Testing for unit roots in heterogeneous panels. Journal of Econometrics, 115: 5374.

Institute of Development Studies, 2006, http://www.id21.org/insights/insights60/art03.html

IMF, 2005, World Economic Outlook, International Monetary Fund, Washington DC.

Jongwanich J (2007)Workers' Remittances, Economic Growth, and Poverty in Developing Asia and Pacific Countries, United nations Economic and Social Commission for Asia and the Pacific (UNESCAP), Working Paper 07/01

Levin A, Lin CF Lin, Chu J (2002) Unit root tests in panel data: asymptotic and finite-sample properties. Journal of Econometrics 108: 1-24.

Maddala GS, Wu S (1999) A comparative study of unit root tests with panel data and a new simple test. Oxford Bulletin of Economics and Statistics 61: 631-652.

Newey WK, West KD (1994) Automatic lag selection in covariance matrix estimation. Review of Economic Studies 61: 631-654.

Otieno J (2010) Remittances to Africa to rise by 2 percent this year. The East African.

Pedroni P (2004) Panel cointegration: Asymptotic and finite sample properties of pooled time series tests with an application to the ppp hypothesis. Econometric Theory 20: 597-625.

Pesaran MH, Shin Y, Smith RP (1997) Estimating long-run relationships in dynamic heterogeneous panels. DAE Working Papers Amalgamated Series 9721.

Pesaran MH, Shin Y, Smith RP (1999) Pooled mean group estimation of dynamic heterogeneous panels. Journal of the American Statistical Association 94: 621-634.

Pesaran MH, Hashem M, Shin Y(1998) An autoregressive distributed lag modeling Approach to Cointegration Analysis. In Econometrics and Economic Theory in the $20^{\text {th }}$ Century: The Ragnar Frisch Centennial Symposium, edi. By Steinar Strom. Cambridge, Massachusetts, Cambridge University Press.

Pesaran MH, Hashem M, Shin, Smith RP (1999) Pooled estimation of long-run relationships in dynamic heterogeneous panels. Journal of the American Statistical Association 94: 621-634.

Ruiz-Arranz M, (2006) Boosting economic growth. Institute of Development Studies http://www.id21.org/insights/insights60/art03.html

Stahl CW, Arnold F (1986) Overseas workers' remittances in Asian development. International Migration Review 20: 899-925.

Stark O, Lucas R (1988) Migration, remittances, and the family. Economic Development and Cultural Change 36 : 465-481. 
Stata 11 Hanbook (2009). StataCorp. Stata: Release 11. Statistical Software. College Station, Texas: StataCorp LP.

Stock J (1987) Asymptotic properties of least squares estimators of cointegrating vectors. Econometrica 55:10351056.

Taylor JE (1992) Remittances and inequality reconsidered: direct, indirect, and inter-temporal effects. Journal of policy Modeling 14:187-208.

Vargas-Silva C, Jha S, Sugiyarto G (2009) Remittances in Asia: Implications for the fight against poverty and the pursuit of economic growth, ADB Economics Working Paper Series

Vanegas M, Croes RR (2003) Growth, development and tourism in a small economy: Evidence from Aruba. International Journal of Tourism Research 5: 315-330.

Westerlund J (2007) Testing for error correction in panel data. Oxford Bulletin of Economics and Statistics 69: 709748.

World Bank, 2008, Remittances and Development: Lessons from Latin America edited by Pablo Fajnzylber and J. Humberto Lopez http://siteresources.worldbank.org/INTLAC/Resources/Remittances_and_Development_Report.pdf 
Table 1a: Data Description and Sources

\begin{tabular}{|l|l|l|}
\hline Variable & \multicolumn{1}{|c|}{ Description } & \multicolumn{1}{c|}{ Source } \\
\hline Per Capita GDP & $\begin{array}{l}\text { Gross domestic product per capita, measured in } \\
\text { constant (2000) US dollars. From the }\end{array}$ & 2010 World Development Indicators Data Set. \\
\hline Remittances & $\begin{array}{l}\text { Per capita workers' remittances and compensation of } \\
\text { employees, received (nominal US dollars). From the } \\
\text { 2007 World Development Indicators Data Set } \\
\text { Openness }\end{array}$ & 2010 World Development Indicators Data Set. \\
\hline Capita/Labor Ratio & $\begin{array}{l}\text { Gross Fixed Capital Formation divided by Labor Force } \\
\text { 14 divided by (Political Rights Index + Civil Liberties } \\
\text { Index times) 100. The political rights and civil indeces } \\
\text { goes from 1 to 7, with 1 denoting the most free and 7 } \\
\text { being least free. Therfore, higher values for our freedom } \\
\text { index denotes more freedom. }\end{array}$ & Freedom House \\
\hline Freedom & 2010 World Development Indicators Data Set. \\
\hline $\begin{array}{l}\text { Note: The is an unbalance panel data which covers the time period from 1985 to 2007, it comprises of 64 countries, including 29 from Africa, 14 from } \\
\text { Asia and 21 from Latin America and the Caribbean. }\end{array}$
\end{tabular}

Table1b. Summary Statistics by Region 


\begin{tabular}{|c|c|c|c|c|c|c|c|}
\hline Area & Variable & \# of Countries & Observations & Mean & Std. Dev. & Min & Max \\
\hline \multirow{5}{*}{ 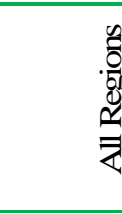 } & Per Capita GDP & \multirow{5}{*}{64} & 1841 & 2233.25 & 3671.15 & 81.01 & 29915.32 \\
\hline & Remittances & & 1727 & 50.54 & 94.02 & 0.00 & 801.10 \\
\hline & Openness & & 1830 & 72.27 & 45.03 & 0.31 & 456.65 \\
\hline & Capital/Labor Ratio & & 1337 & 1031.16 & 1501.47 & 1.00 & 18672.38 \\
\hline & Freedom & & 1965 & 234.63 & 160.47 & 100.00 & 700.00 \\
\hline & & & & & & & \\
\hline \multirow{5}{*}{ 递 } & Per Capita GDP & \multirow{5}{*}{29} & 838 & 705.10 & 812.80 & 81.01 & 4541.05 \\
\hline & Remittances & & 800 & 31.91 & 54.14 & 0.00 & 286.21 \\
\hline & Openness & & 835 & 66.13 & 34.71 & 6.32 & 209.41 \\
\hline & Capital/Labor Ratio & & 663 & 521.69 & 604.63 & 1.00 & 2788.16 \\
\hline & Freedom & & 898 & 174.95 & 100.72 & 100.00 & 700.00 \\
\hline & & & & & & & \\
\hline \multirow{5}{*}{$\frac{\pi}{4}$} & Per Capita GDP & \multirow{5}{*}{14} & 400 & 4067.62 & 6768.83 & 186.44 & 29915.32 \\
\hline & Remittances & & 334 & 21.35 & 29.44 & 0.05 & 206.35 \\
\hline & Openness & & 402 & 71.60 & 64.89 & 0.31 & 456.65 \\
\hline & Capital/Labor Ratio & & 304 & 1587.92 & 2667.11 & 63.95 & 18672.38 \\
\hline & Freedom & & 464 & 168.78 & 71.88 & 100.00 & 466.67 \\
\hline \multirow{5}{*}{ 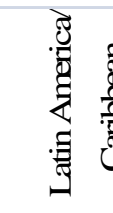 } & & \multirow{5}{*}{21} & & & & & 1016805 \\
\hline & $\begin{array}{l}\text { Per Capita GDP } \\
\text { Remittances }\end{array}$ & & $\begin{array}{l}603 \\
593\end{array}$ & $\begin{array}{r}3140.11 \\
92.13\end{array}$ & $\begin{array}{r}1896.64 \\
136.54\end{array}$ & $\begin{array}{r}402.02 \\
0.05\end{array}$ & $\begin{array}{r}10168.05 \\
801.10\end{array}$ \\
\hline & Openness & & 593 & 81.37 & 39.74 & 14.39 & 198.77 \\
\hline & Capital/Labor Ratio & & 370 & 1486.62 & 857.64 & 227.63 & 4150.89 \\
\hline & Freedom & & 603 & 374.19 & 191.72 & 100.00 & 700.00 \\
\hline
\end{tabular}

Table 2: Panel Unit Roots Test Results by Regions (Levels)

\begin{tabular}{|c|c|c|c|c|c|c|c|c|c|c|c|c|c|}
\hline \multirow{3}{*}{ GDP Per Capita } & \multirow{3}{*}{ Test Statistic } & \multicolumn{3}{|c|}{ All Regions } & \multirow{2}{*}{\multicolumn{3}{|c|}{$\begin{array}{c}\text { Africa } \\
\text { Statistic Pvalue }\end{array}$}} & \multirow{2}{*}{\multicolumn{3}{|c|}{$\frac{\text { Asia }}{\text { Statisti Pvalue }}$}} & \multicolumn{3}{|c|}{ Latin America/Cribbean } \\
\hline & & \multirow{2}{*}{ Statistic } & \multirow[t]{2}{*}{ Pvalue } & & & & & & & & \multirow{2}{*}{ Statistic } & \multirow{2}{*}{ Pvalue } & \\
\hline & & & & & \multirow{2}{*}{91.415} & \multirow{2}{*}{0.003} & \multirow[b]{2}{*}{$* * *$} & \multicolumn{2}{|c|}{\begin{tabular}{l|l} 
& \\
\end{tabular}} & & & & \\
\hline Inverse chi-squared & $P$ & 202.199 & 0.000 & $* * *$ & & & & 64.759 & 0.000 & *** & 54.874 & 0.088 & * \\
\hline Inverse normal & Z & -1.155 & 0.124 & & -1.838 & 0.033 & ** & -2.065 & 0.020 & ** & -0.507 & 0.306 & \\
\hline Inverse logit & $\mathrm{L}^{*}$ & -2.073 & 0.020 & ** & -2.198 & 0.015 & ** & -3.008 & 0.002 & *** & -0.851 & 0.198 & \\
\hline Modified inv. chi-squared & $\mathrm{Pm}$ & 4.637 & 0.000 & $* * *$ & 3.103 & 0.001 & *** & 4.912 & 0.000 & *** & 1.405 & 0.080 & * \\
\hline \multicolumn{14}{|l|}{ Remittances } \\
\hline Inverse chi-squared & $\mathrm{P}$ & 206.085 & 0.000 & $* * *$ & 95.517 & 0.001 & ** & 60.667 & 0.000 & **** & 118.739 & 0.000 & *** \\
\hline Inverse normal & z & -1.335 & 0.091 & * & -1.839 & 0.033 & ** & -2.429 & 0.008 & $* * *$ & -2.062 & 0.020 & ** \\
\hline Inverse logit & $\mathrm{L}^{*}$ & -3.012 & 0.001 & $* * *$ & -2.282 & 0.012 & ** & -3.391 & 0.001 & *** & -4.740 & 0.000 & *** \\
\hline Modified inv. chi-squared & $\mathrm{Pm}$ & 5.383 & 0.000 & $* * *$ & 3.734 & 0.000 & $* * *$ & 5.292 & 0.000 & *** & 8.373 & 0.000 & $* * *$ \\
\hline \multicolumn{14}{|l|}{ Openness } \\
\hline Inverse chi-squared & $\mathrm{P}$ & 223.063 & 0.000 & $* * *$ & 140.388 & 0.000 & *** & 29.458 & 0.596 & & 56.019 & 0.073 & $3 *$ \\
\hline Inverse normal & Z & -2.523 & 0.006 & $* * *$ & -4.178 & 0.000 & *** & 1.451 & 0.927 & & -1.132 & 0.129 & \\
\hline Inverse logit & $\mathrm{L}^{*}$ & -3.422 & 0.000 & $* * *$ & -5.371 & 0.000 & *** & 1.554 & 0.938 & & -1.349 & 0.090 & * \\
\hline Modified inv. chi-squared & $\mathrm{Pm}$ & 5.440 & 0.000 & $* * *$ & 7.338 & 0.000 & *** & -0.318 & 0.625 & & 1.530 & 0.063 & $3 *$ \\
\hline \multicolumn{14}{|l|}{ Capital/Labor Ratio } \\
\hline Inverse chi-squared & $\mathrm{P}$ & 182.553 & 0.0091 & $* * *$ & 80.861 & 0.08 & * & 33.72 & 0.48 & & 81.5474 & 0.0002 & **** \\
\hline Inverse normal & Z & -0.0738 & 0.4706 & & -0.0209 & 0.49 & & -0.265 & 0.4 & & -2.4681 & 0.0068 & $3 * * *$ \\
\hline Inverse logit & $\mathrm{L}^{*}$ & -0.6045 & 0.273 & & 0.2275 & 0.59 & & -0.299 & 0.38 & & -3.1434 & 0.0011 & *** \\
\hline Modified inv. chi-squared & $\mathrm{Pm}$ & 2.543 & 0.0055 & $* * *$ & 1.4903 & 0.07 & * & -0.034 & 0.51 & & 4.315 & 0 & *** \\
\hline \multicolumn{14}{|l|}{ Freedom } \\
\hline Inverse chi-squ & $\mathrm{P}$ & 145.711 & 0.2691 & & 46.202 & 0.93 & & 41.15 & 0.13 & & 54.5062 & 0.0934 & $4 *$ \\
\hline Inverse normal & z & 0.6496 & 0.742 & & 1.2498 & 0.89 & & 0.049 & 0.52 & & 0.1055 & 0.542 & \\
\hline Inverse logit t & $\mathrm{L}^{*}$ & 0.3696 & 0.6441 & & 1.2182 & 0.89 & & -0.253 & 0.4 & & -0.2659 & 0.3954 & \\
\hline Modified inv. chi-squared & $\mathrm{Pm}$ & 0.5888 & 0.278 & & -1.4187 & 0.92 & & 1.143 & 0.13 & & 1.3645 & 0.0862 & 2 * \\
\hline
\end{tabular}


Table 3: Panel Unit Roots Test Results by Regions (First Differences)

\begin{tabular}{|c|c|c|c|c|c|c|c|c|c|c|c|c|c|}
\hline \multirow{3}{*}{ GDP Per Capita } & & \multicolumn{3}{|c|}{ All Regions } & \multicolumn{3}{|c|}{ Africa } & \multirow{2}{*}{\multicolumn{3}{|c|}{$\frac{\text { Asia }}{\text { Statistic Pvalue }}$}} & \multicolumn{3}{|c|}{ Latin America/Cribbean } \\
\hline & & \multirow[t]{2}{*}{ Statistic } & \multicolumn{2}{|l|}{ Pvalue } & \multicolumn{3}{|c|}{ Statistic Pvalue } & & & & \multirow[t]{2}{*}{ Statistic } & \multirow[t]{2}{*}{ Pvalue } & \\
\hline & & & & & & & & & & & & & \\
\hline Inverse chi-squared(128) & $\mathrm{P}$ & 445.434 & 0.000 & $* * *$ & 242.383 & 0.000 & $* * *$ & 106.191 & 0.000 & $* * *$ & 114.370 & 0.000 & $* * *$ \\
\hline Inverse normal & z & -13.053 & 0.000 & $* * *$ & -9.718 & 0.000 & $* * *$ & -6.845 & 0.000 & $* * *$ & -6.004 & 0.000 & $* * *$ \\
\hline Inverse logit t(324) & $\mathrm{L}^{*}$ & -14.693 & 0.000 & $* * *$ & -11.858 & 0.000 & $* * *$ & -7.677 & 0.000 & $* * *$ & -6.361 & 0.000 & $* * *$ \\
\hline Modified inv. chi-squared & $\mathrm{Pm}$ & 19.840 & 0.000 & $* * *$ & 17.120 & 0.000 & $* * *$ & 10.449 & 0.000 & $* * *$ & 7.896 & 0.000 & $* * *$ \\
\hline \multicolumn{14}{|l|}{ Remmittances } \\
\hline Inverse chi-squared(122) & $\mathrm{P}$ & 543.335 & 0.000 & $* * *$ & 301.582 & 0.000 & $* * *$ & 90.041 & 0.000 & $* * *$ & 219.635 & 0.000 & $* * *$ \\
\hline Inverse normal & Z & -15.737 & 0.000 & $* * *$ & -12.562 & 0.000 & $* * *$ & -6.111 & 0.000 & $* * *$ & -10.536 & 0.000 & $* * *$ \\
\hline Inverse logit t(309) & $L^{*}$ & -18.705 & 0.000 & $* * *$ & -15.553 & 0.000 & $* * *$ & -7.004 & 0.000 & $* * *$ & -13.072 & 0.000 & $* * *$ \\
\hline Modified inv. chi-squared & $\mathrm{Pm}$ & 26.973 & 0.000 & $* * *$ & 23.205 & 0.000 & $* * *$ & 9.532 & 0.000 & *** & 19.382 & 0.000 & $* * *$ \\
\hline \multicolumn{14}{|l|}{ Openness } \\
\hline Inverse chi-squared(132) & $P$ & 583.054 & 0.000 & $* * *$ & 297.924 & 0.000 & $* * *$ & 136.252 & 0.000 & $* * *$ & 176.190 & 0.000 & $* * *$ \\
\hline Inverse normal & Z & -16.495 & 0.000 & $* * *$ & -12.584 & 0.000 & $* * *$ & -8.289 & 0.000 & $* * *$ & -8.119 & 0.000 & $* * *$ \\
\hline Inverse logit t(334) & $L^{*}$ & -19.688 & 0.000 & $* * *$ & -15.155 & 0.000 & $* * *$ & -9.929 & 0.000 & $* * *$ & -10.250 & 0.000 & $* * *$ \\
\hline Modified inv. chi-squared & $\mathrm{Pm}$ & 27.430 & 0.000 & $* * *$ & 21.719 & 0.000 & $* * *$ & 13.032 & 0.000 & $* * *$ & 14.641 & 0.000 & $* * *$ \\
\hline \multicolumn{14}{|c|}{ Capital/Labor Ratio } \\
\hline Inverse chi-squared(140) & $\mathrm{P}$ & 579.414 & 0.000 & $* * *$ & 337.236 & 0.000 & $* * *$ & 143.368 & 0.000 & $* * *$ & 201.262 & 0.000 & $* * *$ \\
\hline Inverse normal & Z & -13.002 & 0.000 & $* * *$ & -12.372 & 0.000 & $* * *$ & -8.571 & 0.000 & $* * *$ & -9.397 & 0.000 & $* * *$ \\
\hline Inverse logit t(354) & $L^{*}$ & -16.676 & 0.000 & $* * *$ & -16.042 & 0.000 & $* * *$ & -9.490 & 0.000 & $* * *$ & -11.925 & 0.000 & $* * *$ \\
\hline Modified inv. chi-squared & $\mathrm{Pm}$ & 26.260 & 0.000 & $* * *$ & 24.151 & 0.000 & $* * *$ & 13.263 & 0.000 & $* * *$ & 17.377 & 0.000 & $* * *$ \\
\hline \multicolumn{14}{|l|}{ Freedom } \\
\hline Inverse chi-squared(136) & $\mathrm{P}$ & 584.013 & 0.000 & $* * *$ & 223.803 & 0.000 & $* * *$ & 117.630 & 0.000 & $* * *$ & 208.416 & 0.000 & $* * *$ \\
\hline Inverse normal & Z & -16.280 & 0.000 & $* * *$ & -9.947 & 0.000 & $* * *$ & -6.834 & 0.000 & $* * *$ & -10.395 & 0.000 & $* * *$ \\
\hline Inverse logit t(344) & $\mathrm{L}^{*}$ & -19.134 & 0.000 & $* * *$ & -10.822 & 0.000 & $* * *$ & -7.833 & 0.000 & $* * *$ & -12.455 & 0.000 & $* * *$ \\
\hline Modified inv. chi-squared & $\mathrm{Pm}$ & 27.165 & 0.000 & $* * *$ & 14.530 & 0.000 & $* * *$ & 10.704 & 0.000 & $* * *$ & 18.158 & 0.000 & $* * *$ \\
\hline
\end{tabular}

Table 4: Westurland Error-Correction Model Test by Region (Westurland, 2007)

\begin{tabular}{|c|c|c|c|c|c|}
\hline Regional Groups & $\mathrm{N}$ & Statistic & Value & $\mathrm{P}$-value & \\
\hline \multirow[t]{4}{*}{ All Regions } & \multirow{4}{*}{64} & Gt & -2.890 & 0.000 & $* * *$ \\
\hline & & $\mathrm{Ga}$ & -18.228 & 0.000 & $* * *$ \\
\hline & & $\mathrm{Pt}$ & -18.225 & 0.015 & $* *$ \\
\hline & & $\mathrm{Pa}$ & -16.310 & 0.000 & $* * *$ \\
\hline \multirow[t]{4}{*}{ Africa } & \multirow{4}{*}{29} & Gt & -2.828 & 0.001 & $* * *$ \\
\hline & & $\mathrm{Ga}$ & -15.658 & 0.002 & $* *$ \\
\hline & & $\mathrm{Pt}$ & -14.009 & 0.000 & $* * *$ \\
\hline & & $\mathrm{Pa}$ & -14.735 & 0.000 & $* * *$ \\
\hline \multirow[t]{4}{*}{ Asia } & \multirow{4}{*}{14} & Gt & -2.183 & 0.772 & \\
\hline & & $\mathrm{Ga}$ & -26.072 & 0.000 & $* * *$ \\
\hline & & $\mathrm{Pt}$ & -6.506 & 0.828 & \\
\hline & & $\mathrm{Pa}$ & -18.704 & 0.000 & $* * *$ \\
\hline \multirow[t]{4}{*}{ Latin America \& Caribbean } & \multirow{4}{*}{21} & Gt & -3.373 & 0.000 & $* * *$ \\
\hline & & $\mathrm{Ga}$ & -17.098 & 0.000 & $* * *$ \\
\hline & & $\mathrm{Pt}$ & -12.639 & 0.000 & $* * *$ \\
\hline & & $\mathrm{Pa}$ & -16.927 & 0.000 & $* * *$ \\
\hline
\end{tabular}

Pvalues are for a one-sided test based on the bootstrap distribution. We use 500 bootstrap replications. ***, and $* *$ denotes significance at the $1 \%$ and $5 \%$ levels respectively. 
Table 5: Panel Fully Modified Ordinary Least Squares Model (PFMOLS)

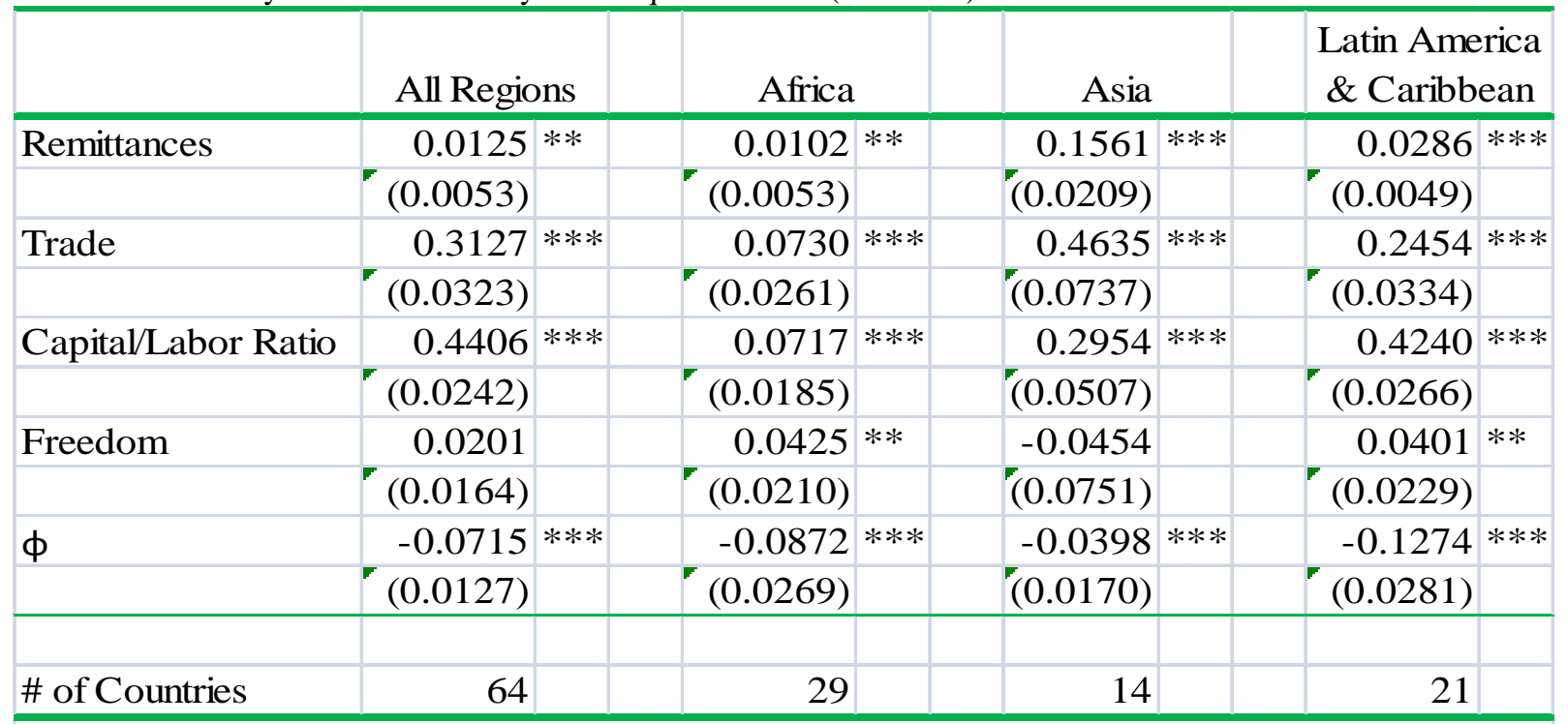

Note: $*, * *, * * *$ denotes significance at the $10 \%, 5 \%$ and the $1 \%$ levels of confidence respectively. The numbers in parenthesis are the standard errors.

Figure 1: Average Annual Growth Rate of Foreign Inflows from 1985 to 2007 for the Whole Area

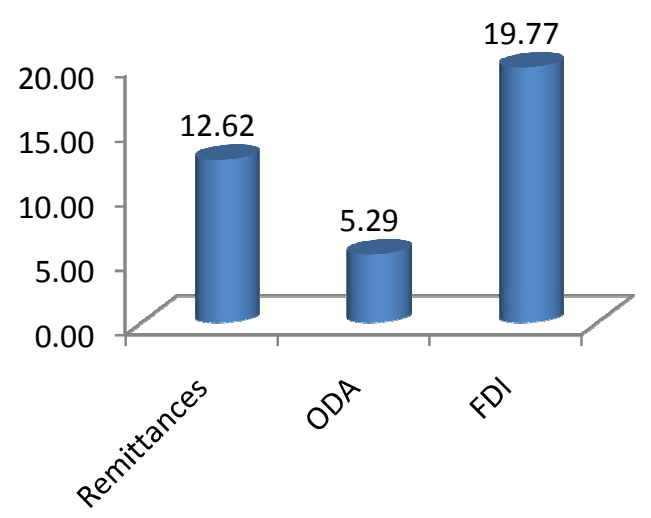

Figure 3: Average Annual Growth Rate of Foreign Inflows from 1985 to 2007 for Asia
Figure 2: Average Annual Growth Rate of Foreign Inflows from 1985 to 2007 for Africa

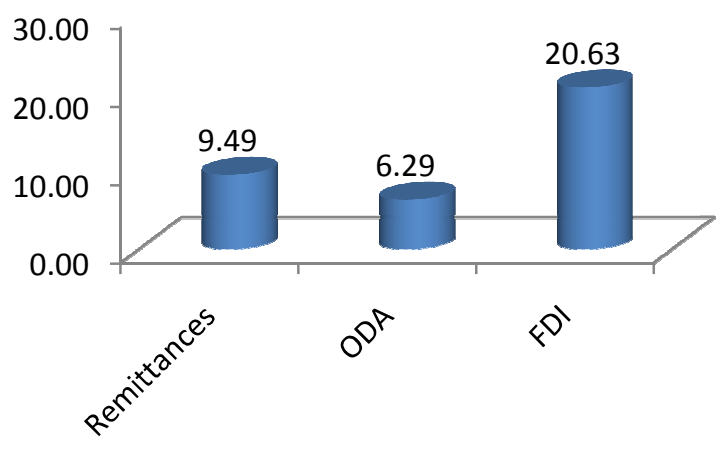

Figure 4: Average Annual Growth Rate of Foreign Inflows from 1985 to 2007 for Latin America/Caribbean 

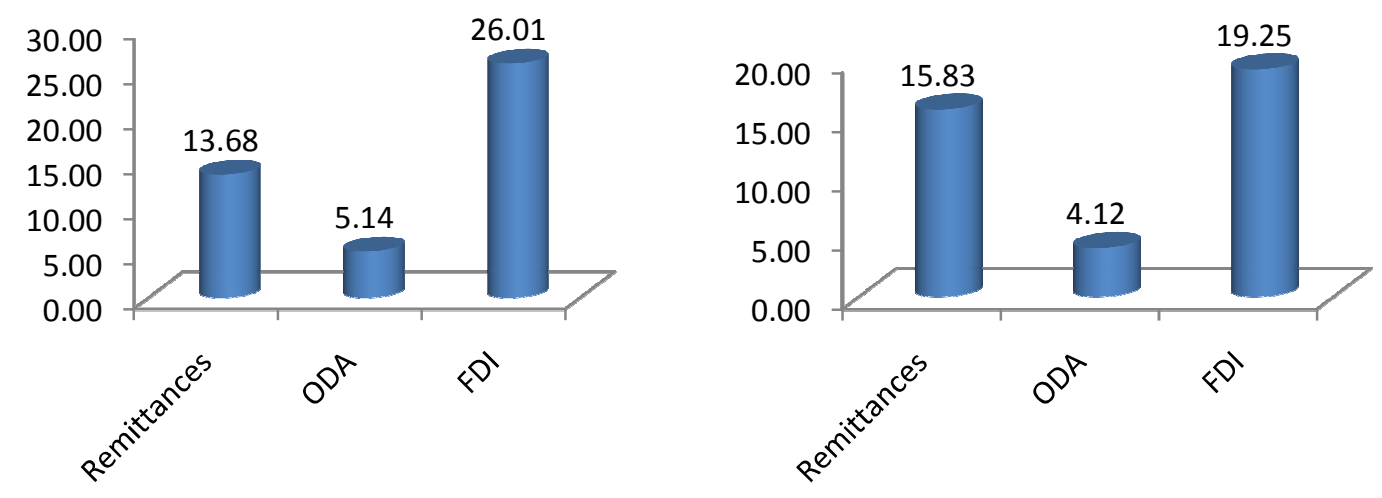

Appendix: Country List

\begin{tabular}{|c|c|c|c|c|}
\hline \multicolumn{2}{|l|}{$\underline{\text { Africa }}$} & \multirow{2}{*}{$\frac{\underline{\text { Asia }}}{\text { Bangladesh }}$} & \multicolumn{2}{|c|}{ Latin America and the Caribbean } \\
\hline Algeria & Lesotho & & Belize & Dominica \\
\hline Benin & Madagascar & Bhutan & Bolivia & Haiti \\
\hline Botswana & Mali & Brunei Darussalam & Brazil & Jamaica \\
\hline Burkina Faso & Mauritania & China & Chile & Panama \\
\hline Cameroon & Mozambique & India & Colombia & St. Kitts and Nevis \\
\hline Cape Verde & Niger & Indonesia & Costa Rica & St. Lucia \\
\hline Central African Republic & Nigeria & Korea, Rep. & Dominican & \\
\hline Comoros & Rwanda & Lao PDR & Ecuador & \\
\hline Congo, Dem. Rep. & Senegal & Malaysia & El Salvador & \\
\hline Cote d'Ivoire & South Africa & Pakistan & Honduras & \\
\hline Egypt, Arab Rep. & Sudan & Philippines & Mexico & \\
\hline Ethiopia & Swaziland & Singapore & Paraguay & \\
\hline Gambia, The & Togo & Sri Lanka & Venezuela, & \\
\hline
\end{tabular}


Barbados 